\title{
Donkey Owners Knowledge and Perception on Reproduction: Case of the Builsa North District, Ghana
}

\author{
J Atawalna ${ }^{1 *}$, CD Essel $^{1}$ and DKD Sia ${ }^{2}$ \\ ${ }^{1}$ School of Veterinary Medicine, Kwame University of Science and Technology, Ghana \\ ${ }^{2}$ Department Veterinary Services, Ejisu, Ghana
}

*Corresponding author: J Atawalna, School of Veterinary Medicine, Kwame University of Science and Technology, Kumasi, Ghana.

Received Date: July 15, 2019

Published Date: July 24, 2019

\begin{abstract}
The study was conducted in the Builsa North district of Ghana, using questionnaire to investigate the knowledge and perception of donkey owners on reproduction and reproductive health problems in their animals. A total of 94 respondents were interviewed. The majority of respondents (42.6\%) observed oestrus in donkeys throughout the year, while the least (7.4\%), associated oestrus with the rainy season. The respondents were able to detect jennies on heat based on clinical signs. The majority of respondents (35.1\%) were able to recognize pregnancy in jennies at 5 months gestation, while (51.1\%) of respondents estimated the gestation period to be 11-12 months. The common reproductive health disorders experienced by jennies were Still births (2.7\%), Abortion (2.4\%), Dystocia (2.2\%), Mastitis (0.4), Retained placenta (0.1\%) and Metritis (0.1\%). Donkey owners are very conversant with donkey reproduction. It is recommended that education on donkey reproduction and reproductive health problems for farmers be intensified in the district.
\end{abstract}

Keywords: Knowledge; Perception; Donkey; Reproduction

\section{Introduction}

The donkey (Equus asinus) is indigenous to the African continent and is believed to have originated from the Nubian wild ass. The largest population of donkeys in the world are found in China, while in Africa, Ethiopia has the largest population estimated to be over five (5) million [1]. In Ghana, an estimated population of 13,100 donkeys are reared mainly in the Northern, Upper East and Upper West regions [2] Donkeys were introduced to the southern parts of Ghana for animal and traction purposes [3].Throughout the world, donkeys have been utilized for multi-purpose activities including as guard animals for protecting small ruminants, companion animals, draught animals and sport animals [4].

Despite their vast economic importance, the donkey population in Africa has been declining over the decades. This has been attributed to the illegal trade in donkey meat for export to China. There is therefore the need to maintain this current population by focusing on donkey reproduction and breeding. Attempts at improving donkey reproductive performance must take into cognisance, the indigenous knowledge of donkey reproductive physiology and breeding. Unfortunately, such information is very scanty in literature. The available information on donkey reproduction is derived from studies done on horses, although there is a fundamental difference between them. The purpose of this study was to investigate the knowledge of donkey owners on donkey reproduction and reproductive health disorders in Northern Ghana.

\section{Materials and Methods}

The study was conducted in the Builsa North district of the Upper East region of Ghana from January to March, 2015. The district lies between longitudes 10 05" West and 10 35" West and latitudes 10020 " North and covers an estimated land area of $816.44030 \mathrm{~km} 2$ [5]. This district was purposively selected due to its great agricultural potential and location. It is located approximately Forty-Five (45) kilometeres from the Upper East regional capital of Bolgatanga.

The respondents were randomly selected, based on an evidence of donkey rearing and interviewed using semi-structured questionnaire, designed to capture information on farmers socio-economic characteristics and their knowledge in donkey 
reproduction and reproductive health disorders. Direct observation of the animals was done in order to assess the nature of the housing and husbandry conditions where applicable. The results obtained were analysed using descriptive statistics.

\section{Results and Discussion}

\section{Socio-economic characteristics of donkey owners}

The respondents interviewed consisted of 69 males and 25 females. Their ages ranged from 25 to 73 years with an average age of 43.2 years. The average age of donkey owners in this study was lower than the age of more than 60 years in Greece [6]. The majority of respondents (47.9\%) had no formal education, 31.9\% had basic education while $20.2 \%$ were graduates of Teacher training or Agricultural colleges. The respondents kept other livestock such as cattle, sheep, goats, chicken and guinea fowls. The herd size ranges from 1-19 donkeys per individual with the majority keeping an average of 4 donkeys per household. The respondents owned a total of 674 donkeys comprising of 338 female and 236 males.

\section{Reproductive traits}

The respondents were interviewed on various aspects of donkey reproductive physiology. This study shown that donkeys attained sexual maturity from age 2-3 years. This result contradicts findings that sexual maturity sets in at age 1-2 years $[7,8]$. The difference may be due to the fact that feeding is usually scarce especially during the dry season. This will account for a delayed onset of sexual maturity in affected animals. Respondents were quizzed on the seasonality of the oestrous cycles. The majority of respondents $(42.6 \%)$ observed oestrus in donkeys throughout the year, while the least (7.4\%), associated oestrus with the rainy season Table 1 . This finding supports the observation that donkeys come into oestrus throughout the year under tropical and subtropical conditions $[8,9]$ Seasonal reproduction in donkeys is controlled by photoperiod and other factors such as feed availability, body condition score, health and environmental conditions [10]. The latter factors appear to be more prominent in the study district which experiences a cold harmattan season and scarcity of feed from December to February annually. Jennies will therefore cycle depending on the prevailing weather conditions and feed availability.

The clinical signs used by donkey owners to detect jennies on heat are listed in descending order as follows: male and female courtship behavior (24.8\%), female mounting other donkeys (13.8\%), vulvar discharge (6.3\%) and red swollen vulva (2.1\%) Table 2. It is therefore apparent that donkey owners are familiar with the signs of oestrus in jennies. The signs of heat in jennies is similar as in animals such as small ruminants, cattle and pigs, which are also reared by donkey owners.

Female donkeys on heat were naturally mated by donkey jacks which sometimes resulted in pregnancy. Donkey owners used signs such as distended abdomen, enlargened udder, non-acceptance for mating by males and weaning of foals to diagnose pregnancy. The majority of respondents (35.1\%) were able to recognize pregnancy in jennies at 5 months gestation, while $3.2 \%$ did so at 2-month gestation Table 3. The majority (51.1\%) of respondents estimated the gestation period to be $11-12$ months, while $6.4 \%$ said it was 7-8 months Table 4. In addition, most respondents (44.7\%) said foaling occurred throughout the year and was not limited to any seasons or months of the year Table 5. This finding supports the view that pregnancy and parturition are less seasonal in domestic donkeys than in wild asses [11] (Tables 1-5).

Table 1: Donkey owners knowledge of time of oestrus.

\begin{tabular}{|c|c|c|}
\hline Parameter & Number of Respondents & \% Respondents \\
\hline Do not know & 13 & 13.8 \\
\hline All year round & 40 & 42.6 \\
\hline Dry season & 34 & 36.2 \\
\hline Rainy season & 7 & 7.4 \\
\hline Total & 94 & 100 \\
\hline
\end{tabular}

Table 2: Donkey owners recognition of oestrus.

\begin{tabular}{|c|c|c|}
\hline Sign & $\begin{array}{c}\text { Number of } \\
\text { Respondents }\end{array}$ & \% Respondents \\
\hline Males chasing females & 25 & 24.5 \\
\hline Female mounting others & 13 & 13.8 \\
\hline Red swollen vulva & 2 & 2.1 \\
\hline Vulvar discharge & 6 & 6.3 \\
\hline $\begin{array}{c}\text { Acceptance of males for } \\
\text { mating }\end{array}$ & 15 & 16.1 \\
\hline No known sign & 35 & 26.6 \\
\hline Total & 94 & 100 \\
\hline
\end{tabular}

Table 3: Age at which pregnancy is first recognized by owners.

\begin{tabular}{|c|c|c|}
\hline Time/month & $\begin{array}{c}\text { Number of } \\
\text { Respondents }\end{array}$ & \% Respondents \\
\hline 2 & 3 & 3.2 \\
\hline 3 & 17 & 18.1 \\
\hline 4 & 25 & 26.6 \\
\hline 5 & 33 & 35.1 \\
\hline 6 & 5 & 5.3 \\
\hline 7 & 7 & 7.4 \\
\hline 8 & 4 & 4.3 \\
\hline Total & 94 & 100 \\
\hline
\end{tabular}

Table 4: Duration of pregnancy.

\begin{tabular}{|c|c|c|}
\hline Gestation period/months & $\begin{array}{c}\text { Number of } \\
\text { Respondents }\end{array}$ & \% Respondents \\
\hline 8-Jul & 6 & 6.4 \\
\hline 10-Sep & 18 & 19.1 \\
\hline 12-Nov & 48 & 51.1 \\
\hline 13-14 & 22 & 23.4 \\
\hline Total & 94 & 100 \\
\hline
\end{tabular}

Table 5: Donkey owners knowledge of time of foaling.

\begin{tabular}{|c|c|c|}
\hline Time of Foaling & $\begin{array}{c}\text { Number of } \\
\text { Respondents }\end{array}$ & \% Respondents \\
\hline All year round & 42 & 44.7 \\
\hline Dry season & 27 & 28.7 \\
\hline Rainy season & 25 & 26.6 \\
\hline Total & 94 & 100 \\
\hline
\end{tabular}




\section{Reproductive health disorders}

Respondents were quizzed on reproductive health disorders experienced in donkeys for the last two years. The results indicated that $8.3 \%$ donkeys had been affected with reproductive disorders within the last two years. Table 6. The common reproductive health disorders experienced by jennies in descending order were Still births (2.7\%), Abortion (2.4\%), Dystocia (2.2\%), Mastitis $(0.4)$, Retained placenta $(0.1 \%)$ and Metritis $(0.1 \%)$. The reported disorders are similar to those reported in equids in India $[12,13]$. No reproductive health disorders were reported in male donkeys (Table 6).

Table 6: Cases of reproductive health problems in donkeys.

\begin{tabular}{|c|c|c|}
\hline Type & Number & \% Prevalence \\
\hline Still birth & 18 & 2.7 \\
\hline Abortion & 16 & 2.4 \\
\hline Mastitis & 3 & 0.4 \\
\hline Metritis & 1 & 0.1 \\
\hline Retained placenta & 1 & 0.1 \\
\hline Dystocia & 15 & 2.2 \\
\hline Total & 54 & 8.3 \\
\hline
\end{tabular}

\section{Conclusion and Recommendation}

Donkey owners are very conversant with donkey reproductive physiology. Reproductive health disorders are a major issue in female donkeys in Northern Ghana. It is recommended to intensify education on donkey reproductive health for farmers. Further investigation should be conducted to identify the microbes responsible for reproductive health disorders.

\section{Acknowledgement}

Our gratitude goes to Mr. Andrews Awuni at the District Veterinary Office, Builsa North and the farmers who cooperated in answering the questionnaire.

\section{Conflicts of Interest}

No conflict of Interest.

\section{References}

1. Starkey P and Starkey M (2004) Regional and world trends in donkey populations. In: Donkeys, people and development. A resource book of these Animal Traction Network for Eastern and Southern Africa (ATNESA), Starkey P and Fielding D (eds). ACP-EU Technical Centre for Agricultural and Rural Cooperation (CTA), Wageningen, Netherlands.

2. Food and Agricultural Organisation (FAO) (1997) www.fao/agp/AGPC/ doc/counprof/Ghana/Ghana.htm.

3. Canacoo EA (1991) Management of the donkey: A southern Ghana experience. In: Fielding D and Pearson RA (eds). Donkeys, mules and horses in tropical agricultural development, University of Edinburgh, UK, pp. 189-193.

4. Atawalna J, Emikpe BO, Sallah EK, Shaibu W and Folitse RD (2015) The Health Problems, Gastrointestinal and Blood Parasites Commonly Associated with Donkeys in the Upper East Region of Ghana. Afr J Biomed Res 18: 37- 41.

5. Ghana Statistical service (2012) 2010 Population and Housing Census. District Analytical Report: Builsa North District, Ghana.

6. Arsenos G, Gelasakis AI and Papadopoulos E (2010) The status of Donkeys (Equus asinus) in Greece. Journal of The Hellenic Veterinary Medical Society 61(3): 212-219.

7. Pugh DG (2002) Donkey Reproduction. AAEP Proceedings 48: 113-114.

8. Fielding D (1988) Reproductive characteristics of the Jenny donkeyEquus asinus: a review. Trop Anim Hlth Prod 20(3): 161-166.

9. Warriach HM, Memon MA, Ahmad N, Norman ST, Ghafar A, et al. (2014) Reproductive Performance of Arabian and Thoroughbred Mares under Subtropical Conditions of Pakistan. Asian Australas J Anim Sci 27(7): 932-936.

10. Miragaya HM, Neid DM and Alonso AE (2018) A review of the Reproductive Biology and Biotechnologies in Donkeys. Journal of Equine Veterinary Sciences 65: 55-61.

11. Ginther OJ, Scraba ST and Bergfelt DR (1987) Review of the Reproductive Biology and Biotechnologies in Donkeys. Journal of Equine Veterinary Sciences 65: 55-61.

12. Ravi SR, Yadav PS, Singh RK, Tailluri TR, Pal Y, et al. (2013) An overview of equine reproductive disorders in indigenous female equids. Journal of Animal Research 3(2): 245-259.

13. Singh BR, Chauban M, Sindhu RK, Gulati BR, Khurama SK, et al. (2010) Diseases prevalent in equids in India: A survey of Veterinary Practitioners. Asian Journal of Animal and Veterinary Advances 5: 143152. 